EMBRYARIDDLE
Aeronautical University

SCHOLARLY COMMONS

\section{International Journal of Aviation,} Aeronautics, and Aerospace

7-19-2016

\title{
Personality types of pilot students: A study of an Australian collegiate aviation program
}

\section{Yi Gao}

Swinburne University of Technology (Australia), yigao@purdue.edu

Stephen Kong

Swinburne University of Technology (Australia),7493797@student.swin.edu.au

Follow this and additional works at: https://commons.erau.edu/ijaaa

Part of the Personality and Social Contexts Commons

\section{Scholarly Commons Citation}

Gao, Y., \& Kong, S. (2016). Personality types of pilot students: A study of an Australian collegiate aviation program. International Journal of Aviation, Aeronautics, and Aerospace, 3(3). https://doi.org/10.15394/ ijaaa.2016.1130

This Article is brought to you for free and open access by the Journals at Scholarly Commons. It has been accepted for inclusion in International Journal of Aviation, Aeronautics, and Aerospace by an authorized administrator of Scholarly Commons. For more information, please contact commons@erau.edu. 


\section{Personality types of pilot students: A study of an Australian collegiate aviation program}

\section{Cover Page Footnote}

Authors of this paper would like to thank Kane Potter, Isabella Rogers, Martin Sango, and Nick Watts for their contributions to the data collection. 
Personality can be described as the dynamic and organised set of characteristics possessed by a person that uniquely influences his or her cognitions, motivations and behaviours in various situations (Ryckman, 2013). From a psychological perspective, personality dimensions can be defined in a multitude of ways, however, there are eight well defined basic aspects of personality. These include psychoanalytic, neo-analytic ego, biological, behaviourist, cognitive, trait, humanistic and interactionist (Friedman \& Schustack, 2012).

Literature shows a range of personality tests have been administered amongst the pilot population, in particular, in the military environment. The availability of military pilots as research subjects has helped the literature to expand in this domain. Chidester, Helmreich, Gregorich and Geis (1991) adopted the Extended Personal Attributes Questionnaire (EPAQ) for U.S. Air Force pilots and revealed three sub groups among these pilots, which were 1) positive instrumental/interpersonal; 2) negative instrumental; and 3) low motivation cluster. Picano (1991) used the Neuroticism-Extraversion-Openness (NEO) personality instrumentation to study 170 experienced U.S. army pilots and identified three distinct personality types, which were 1) affiliate and outgoing; 2) emotionally controlled, apprehensive, inhibited and socially retiring; and 3) highly independent, competitive and decisive. Research by Bartram (1995) concluded consistent findings within military pilots. Through the use of the Eysenck Personality Inventory (EPI) and Cattell's 16 Personality Factor Questionnaire (16PF), the sampled military pilots were described to be highly self-selected, more emotionally stable and more extraverted than the general population.

Through the use of the NEO personality inventory, Callister (1999) was able to utilise the data of 1,301 U.S. Air Force student pilots to distinguish consistent profiles. Given the wealth of its sample size and its participants, this study was able to explore the additional variable of gender. It was concluded that the average male pilot was altruistic yet highly competitive, sceptical and tough-minded. Components of worthy achievement, great competency, high responsibility and the ability to cope with high levels of stress were observed. Compared with the general male adult norms, it was noted that the male student pilot sample had greater levels of extraversion and lower levels of agreeableness. Female student pilots were observed to be active, assertive and outgoing. They were competitive in nature, tough-minded and highly achievement oriented. Interestingly, it was noted female students showed very similar characteristics to the male sample, that is, they showed higher levels of extraversion and openness and lower levels of agreeableness in comparison to the general population.

Similar findings were established on a study of naval student aviators and flight officers. Lambirth, Doglin, Rentmeister-Bryant and Moore (2009) administered the Tridimensional Personality Questionnaire (TPQ) to find the presumable genetic 
independent aspects of personality amongst 129 aviation students. It was concluded that a strong sense of achieving high goals and engagement amongst constructive activity within achieving their goals were significant.

Although a vast majority of literature falls under the military setting, there are studies that have explored pilots within civil commercial operations. Hormann and Maschke (1996) used Temperament Structure Scales (TSS) and found airline pilots could be characterised by strong factors of sociability, well-balanced selfassertiveness and strong orientation towards actions and activity. Other personality traits included the need for mastery and expressivity along with low scores associated with arrogance and hostility. Qualitative research as published by NASA (Fitzgibbons, Schutte \& Davis, 2004) through the use of a general personality inventory (NEO-PI-R) provides strong pilot profiles. Ninety-three commercial pilot participants from 14 different airlines helped uncover data amid five dimensions: Neuroticism, Extraversion, Agreeableness, Openness and Conscientiousness facets. The basic "pilot personality profile" was described as being emotionally stable, having low levels of anxiety, vulnerability, hostility, impulsiveness and depression. Other notable items include highly conscientious, high in deliberation, achievement striving, highly competent and dutifulness. The pilot profile also describes the individual as active with high levels of assertiveness. Through the use of the Myers-Briggs Type Indicator (MBTI), Hamilton (2007) provided dimensional profiles of 52 commercial flight officers. It was concluded that there was a significant personality type with successful informal group leaders holding dimensions of either extroversion, intuition, thinking and judging (ENTJ) or extroversion, sensing, thinking and judging (ESTJ) within the MBTI category.

Although literature indicates strong reoccurring traits and characteristics within pilots in general, some researchers have also compared civil pilots to military pilots. For instance, Ramachandran, Wadhawan, Chandramohan and Rao (1983), through the use of 16 Personality Factors Inventory (16PF), showed commercial pilots having greater significance in extraversion than military pilots.

There is also some limited literature focusing on personality types of the student pilot population. Roen (1991) studied 222 pilot students at the University of North Dakota. Through the use of the MBTI, three strong categories were confirmed twenty-one percent of the sample showed the profile of extraversion, sensing, thinking and judging (ESTJ) type. This conforms to Hamilton's (2007) study of civil commercial pilots which also displayed the same dominance in the ESTJ category type. The second highest at $10.3 \%$ was categorised as introverted, sensing, thinking and judging (ISTJ), while the third largest group also at $10.3 \%$ held extroversion, sensing, thinking and perceiving (ESTP). It was noted that these top groups all contained the elements of sensing and thinking (ST) which justifies the 
importance of a pilot's ability to use all five senses, especially in relation to psychomotor performance.

Another study (Robertson \& Putnam, 2008) which also utilised student pilots at the University of Illinois and the MBTI showed differing results to Roen's (1991) study. Notably, the highest percentile categories were of extraversion, intuition, feeling and perceiving (ENFP) at 13.25\%; introversion, sensing, thinking and perceiving (ISTP) at 12.05\%; introversion, sensing, thinking and judging (ISTJ) at 10.84\%; extraversion, intuitive, thinking and perceiving (ENTP) at ten percent and introversion, intuitive, feeling and perceiving (INFP) at $9.64 \%$.

In an attempt to discover more about commercial and general aviation pilots, Dillinger, Wiegmann and Taneja (2003) utilised the student pilots at the University of Illinois to explore their personalities and coping strategies. Using the 16PF, 50 undergraduate student pilots showed conforming results to Ramachandran et al., (1983), in which heightened elements of extraversion were observed in comparison to the general population. Furthermore, a more recent study using the NeuroticismExtraversion-Openness Personality Inventory Revised (NEO PI-R) revealed consistent findings relating to extraversion. 9,641 students selected for pilot training as part of the Specialised Undergraduate Pilot Training (SUPT) taught at either Columbus, Laughlin or Vance Air Force Base displayed above the normative mean score for extraversion and additionally conscientiousness (Carretta et al., 2014).

Throughout the body of literature across all three pilot cohorts mentioned in this article, there are consistent personality scales that reoccur. It must be noted that different personality instruments are administered where definitions of personality scales are less conforming to other inventories, although some have evidently surfaced. Notably, pilots are seen to be more emotionally stable (Picano, 1991; Fitzgibbons et al., 2004), highly conscientious (Fitzgibbons et al., 2004; Carretta et al., 2014), highly assertive (Hormann \& Maschke, 1996; Callister, 1999; Fitzgibbons et al., 2004), achievement striving (Hormann \& Maschke, 1996; Callister, 1999; Lambirth et al., 2009), highly competitive (Picano, 1991; Callister, 1999); tough-minded (Bartram,1995; Callister, 1999) and show elevated levels of extraversion (Ramachandran et al., 1983; Bartram, 1995; Callister, 1999; Dillinger et al., 2003; Hamilton, 2007; Carretta et al., 2014). Within the realms of the MBTI, personality categories of extraversion, sensing, thinking and judging (ESTJ) types have been observed (Roen, 1991; Hamilton, 2007).

Besides the need to better understand psychological traits of the pilot population, studies of pilots' personality types usually carry the mission of assisting pilot selection and predicting future training success. Amongst these studies, researchers have deemed some instruments such as the NEO-PI-R to be suitable in the facilitation of pilot selection (Fitzgibbons et al., 2004). Other survey inventories 
measuring various pilot performance data have resulted in consistent traits and have concluded that personality interacts with job performance (Lambirth et al., 2009). Performance tasks included check flights (Hormann \& Maschke, 1996), emergency command ability (Flin \& Slaven, 1996), stress coping strategies (Dillinger et al., 2003), cognitive ability (Carretta et al., 2014), Machiavellianism (Hamilton, 2007) and crew coordination (Chidester et al., 1991). The motivation of these studies was that a specific personality attributing to the success in future flight training could be identified. Albeit, studies soon realised the complexity in defining "typical" aviator portraits (Ganesh \& Joseph, 2005).

Some studies do not go as far as measuring performance, but rather seek the use of a simple personality inventory such as the MBTI to help understand if there is a significant personality type within the population being studied (Roen, 1991; Robertson \& Putnam, 2008). These studies have focused their attention on civil student pilot populations as to help better understand selection and recommend future studies that involve student pilots to include performance measurements (Robertson \& Putnam, 2008).

Although there has not been a definitive instrument nor a definitive set of personality traits to which will grant "golden" passage for one to be a successful pilot, studies have agreed in notion that personality inventories make a contribution to the selection process and are a viable and beneficial source of practical application (Chidester et al., 1991; Roen, 1991; Rose, 2001). This notion, along with an employer's concern over an employee's psychological well-being transposes the need to assess a new candidate for selection (Ganesh \& Joseph, 2005). Major airlines have led the way showing that personality tests are incorporated in selection but are not the 'be all or end all'. Qantas utilises the Occupational Personality Questionnaire (OPQ) as part of pilot selection as with Cathay Pacific who incorporates the Cattells 16PF (Flin \& Slaven, 1996).

From the above review of literature, it can be seen that much of the past research surrounding personality and pilots mostly focus on military and civil commercial operations, with very few looking at the civil ab-initio flight-training environment. And most of the studies were conducted in the U.S., thus calling for more studies addressing the same topic in other regions to see if similar findings can be found with more diverse samples. Therefore, the present study aims to investigate the personality types of pilot students of an Australian university aviation program with the following objectives:

Objective 1: To investigate the dominant personality scale within the pilot student sample using an appropriate instrument;

Objective 2: To investigate the difference in personality scales between pilot students and non-pilot university students. 


\section{Method}

\section{Sample}

Participants of this study are students enrolled in a three-year Bachelor of Aviation single degree or a four-year Bachelor of Aviation/Business double degree program in Melbourne, Australia. The academic component of both aviation programs takes place in the metropolitan campus of the university, and the flying component is delivered at a general-aviation airport in the southeast suburb of Melbourne by a contracted flight-training provider. Students are expected to obtain Commercial Pilot Licence (CPL) by the end of the second year, and have an option to do a Multi Crew Cooperation and Jet Orientation program or Flight Instructor Rating at their own choice in the third year. Both programs have a combined annual intake of 60 - 70 students, and there are approximately 200 students currently active in the program.

\section{Survey Instrument}

The survey instrument used in this study is the Australian Personality Inventory (API), a 50-item instrument measuring the five-factor model of personality (FFM) (Murray et al., 2009) (See Appendix for details). In the original study where this instrument was validated, the university student sample was also from the same university, which makes it convenient to be compared with the results of this study. Another practical consideration of choosing API was due to the free access and availability of this instrument.

The 50 phrases used by the API are retrieved from Goldberg's International Personality Item Pool. Ten phrases each are distributed to measure the five scales of $(\mathrm{N})$ Neuroticism, (E) Extraversion, (O) Openness to experience, (A) Agreeableness and (C) Conscientiousness. An example phrase from the API in which measures (N) Neuroticism is "Often feel blue". Participants used Likert type scale ranging from "very inaccurate", "moderately inaccurate", "neither inaccurate nor accurate", "moderately accurate" to "very accurate" to indicate their responses. Out of the 50 items, half of the items are reverse scored (Items 3, 26 to 32, and 34 to 50) because of the way they were phrased. For instance, the survey item "Seldom feel blue", which was designed to evaluate neuroticism, is reverse scored, as answering "moderately accurate" or "very accurate" means low in neuroticism.

In addition to personality measurement, a short question bank of demographic data was also included in the survey instrument. Demographic data of age, pilot experience (in hours and license type), year level and aviation program were asked in order to get a basic understanding of the survey participants. 


\section{Data Collection}

This study was approved by the human research ethics committee of the university. Responses were collected from pilot students in late September 2015 in typical classroom settings either on university campus or at the training facility in the airport. Hard copy survey questionnaires were distributed to participants by a team composed of at least two researchers. Participants were briefed about purposes of the study, ethics considerations, participants' rights and responsibilities, and instructions in completing the survey. The participation of the survey was voluntary and anonymous. No identifiable information was collected from participants. Participants had the right to refuse to take the survey or withdraw at any time without penalties of any kind. It is assumed that those who chose to participate in the study would answer all survey items honestly.

\section{Data Analysis}

Participants' responses to survey items of the API were scored either normally or in a reversed manner as instructed. Then the overall mean value for each scale was calculated for every participant. For instance, items 2, 7, 12, 17, 22, 27, 32, 37, 42 and 47 represent the scale Extraversion (E) (Refer to Table 1). This allowed for the scales to be ranked by their respective mean scores so that the most dominant and least dominant scale could be identified for all participants, and subsequently, allowed for the distribution of personality scales to be analyzed for the aviation student sample. Results of pilot students were compared with the psychology student sample used by Murray et al. (2009).

Table 1

API Item number and associated personality scale

\begin{tabular}{|l|l|}
\hline Scale & API Item numbers \\
\hline (N) Neuroticism & $1,6,11,16,21,26,31,36,41,46$ \\
\hline (E) Extraversion & $2,7,12,17,22,27,32,37,42,47$ \\
\hline (O) Openness to experiences & $3,8,13,18,23,28,33,38,43,48$ \\
\hline (A) Agreeableness & $4,9,14,19,24,29,34,39,44,49$ \\
\hline (C) Conscientiousness & $5,10,15,20,25,30,35,40,45,50$ \\
\hline
\end{tabular}

\section{Results}

Data collection of this study was conducted in mid-October, 2015, using convenience sampling. A total number of 103 completed questionnaires were collected from pilot students who agreed to participate.

\section{Demographics}

Among the 103 participants, 58 were between 18-20 years of age, 24 were between 21-22 years of age, 14 were between 23-25 years of age and 7 were greater 
than 25 years of age at the time of data collection. Ninety-three participants spent most of their time in Australia prior to turning 18 years of age, 2 spent most of their time in Singapore, whilst 8 participants spent most of their time in France, Italy, Philippines, South Korea, India, Egypt, Latvia and China respectively. Sixty-six participants were enrolled in the Bachelor of Aviation single degree program, whilst 37 were enrolled in the Bachelor of Aviation/Bachelor of Business double degree. Thirty-nine participants were in their $2^{\text {nd }}$ year of studies, 33 were in $1^{\text {st }}$ year, 25 were in $3^{\text {rd }}$ year and 6 were in their $4^{\text {th }}$ year. Sixty-three participants held a Private Pilot Licence (PPL), 28 held a Commercial Pilot Licence (CPL), 7 held a Recreational Pilot Licence (RPL) and 5 participants held a Student Pilot Licence (SPL). Thirty-seven participants held in excess of 151 flight hours, 33 held between 101-150 flight hours, 18 had 51-100 flight hours and 15 participants held between 21-50 flight hours.

\section{Personality Type Scales}

Students' responses to the API enabled an analysis of their personality scales. Amongst this student pilot sample, (A) 'Agreeableness' (36.84\%) was the most dominant personality scale, followed by (C) 'Conscientiousness' (27.19\%); (O) 'Openness to experience' (20.18\%); (E) 'Extraversion' (13.16\%) and (N) 'Neuroticism' (2.63\%). See Figure 1 for details.

Using the same pool of data and method, this study also examined the least dominant personality scale. It was found that $(\mathrm{N})$ 'Neuroticism' was the least dominant (83.65\%) among survey participants, followed by (A) 'Agreeableness' (8.65\%), (E) 'Extraversion' (3.85\%), (C) 'Conscientiousness' (2.88\%) and (O) 'Openness to experience' $(0.96 \%)$. See Figure 2 for details.

\section{Pilot students and non-pilot students}

To test if there is any significant difference between pilot students and non-pilot students on the five API personality scales, the data for the non-pilot student sample from a previous study (Murray et al., 2009) was used to compare with responses collected by this study. Refer to Table 2 for the summary data of the non-pilot student sample, and Table 3 for the summary data of the pilot student sample. 
International Journal of Aviation, Aeronautics, and Aerospace, Vol. 3 [2016], Iss. 3, Art. 6

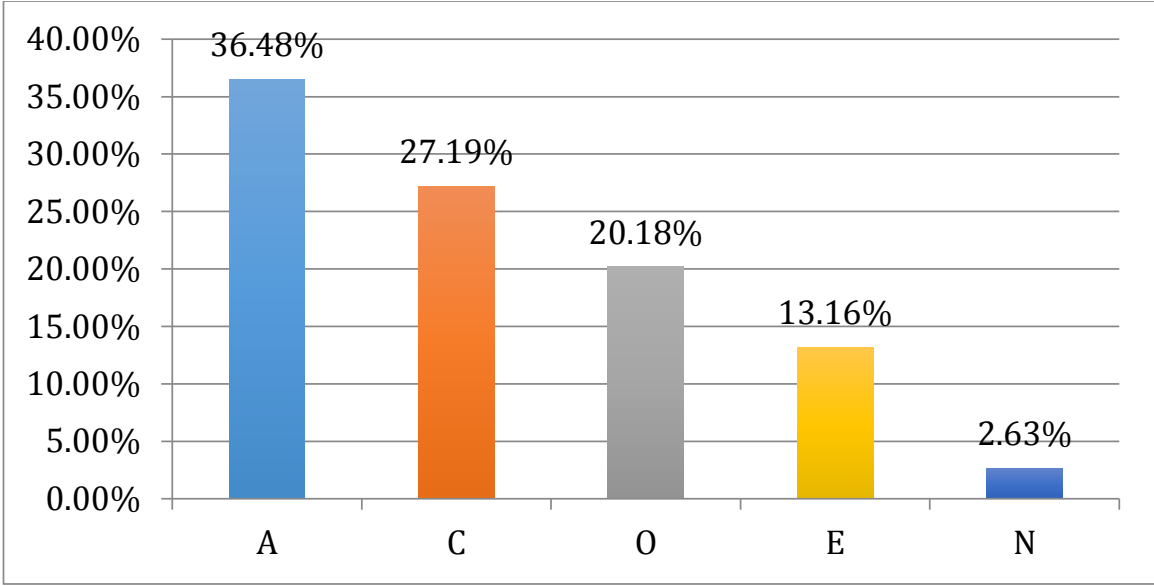

Figure 1. Most dominant personality scale amongst the pilot student sample.

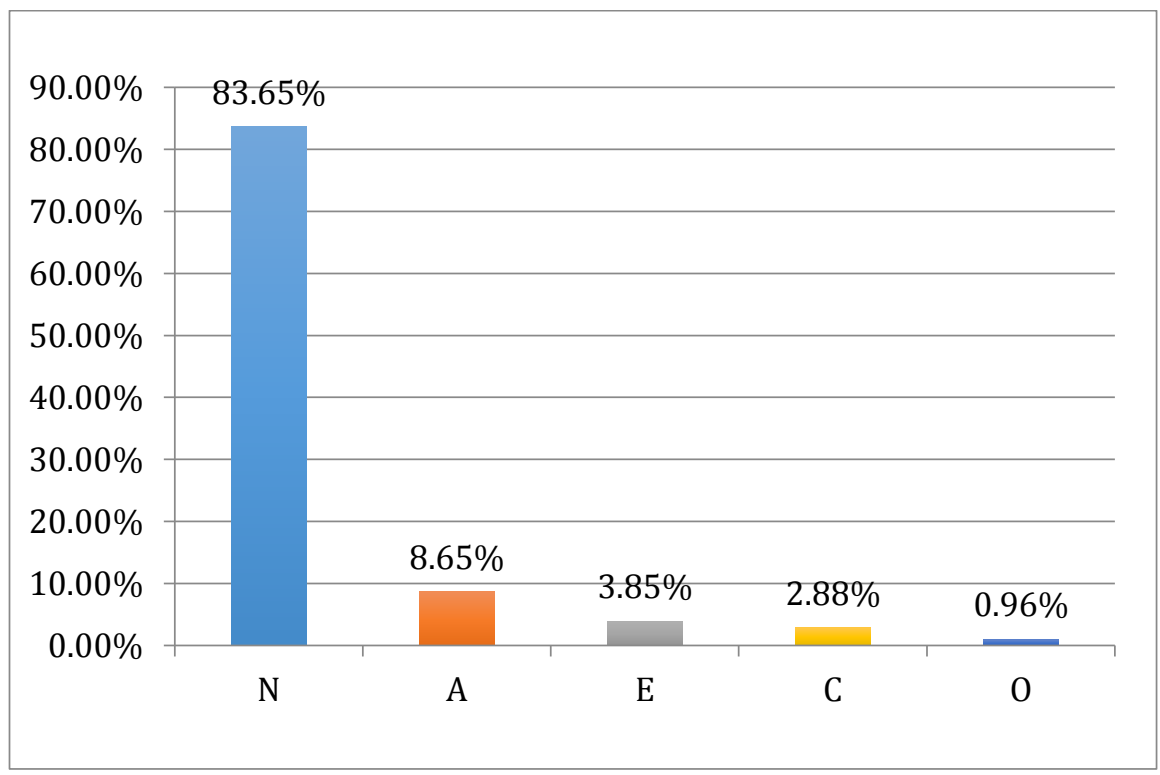

Figure 2. Least dominant personality scale amongst the pilot student sample. 
Table 2

Non-pilot university student summary data (Murray et al., 2009) $(N=271)$

\begin{tabular}{lcc}
\hline Scale & M & SD \\
\hline N & 25.7 & 7.2 \\
E & 34.3 & 6.2 \\
O & 36.4 & 5.9 \\
A & 37.7 & 5.4 \\
C & 36.1 & 6.1 \\
\hline
\end{tabular}

Table 3

Student pilot summary data $(N=103)$

\begin{tabular}{lcc}
\hline Scale & M & SD \\
\hline N & 21.6 & 9.7 \\
E & 34.4 & 9.3 \\
O & 36 & 9.6 \\
$\mathrm{~A}$ & 38.4 & 8.9 \\
$\mathrm{C}$ & 36.9 & 9.8 \\
\hline
\end{tabular}

Each of the five personality scales from two sets of summary data located above was used in an independent sample $t$-test performed by STATA data analysis statistical package version 13 to assess if there was a significant difference between the pilot students and non-pilot university students. In this process, unequal variances were assumed.

Among the five scales, only the comparison of Neuroticism (N) scores was found to be significant (refer to Table 4) under the significance level of 0.05 ( $p<$ 0.001). This suggested that pilot students were characterised by lower neuroticism than non-pilot university students.

Except for Neuroticism (N), statistical analysis did not find any significance between pilot students and non-pilot students on other four API scales. Refer to Tables 5-8 for statistical analysis results on Extraversion (E), Openness to experience (O), Agreeableness (A), and Conscientiousness (C) scales. 
Table 4

Neuroticism t-test between pilot students and non-pilot students

\begin{tabular}{|c|c|c|c|c|c|c|c|}
\hline \multirow[t]{3}{*}{ (N) Neuroticism } & \multicolumn{7}{|c|}{ T-test for Equality of Means } \\
\hline & \multirow[b]{2}{*}{$\mathrm{t}$} & \multirow[b]{2}{*}{$\mathrm{df}$} & \multirow[b]{2}{*}{ Sig. (2-talied) } & \multirow{2}{*}{$\begin{array}{c}\text { Mean } \\
\text { Difference }\end{array}$} & \multirow{2}{*}{$\begin{array}{l}\text { Std. Error } \\
\text { Difference }\end{array}$} & \multicolumn{2}{|c|}{$\begin{array}{l}95 \% \text { Confidence } \\
\text { Interval of the } \\
\text { Difference } \\
\end{array}$} \\
\hline & & & & & & Lower & Upper \\
\hline $\begin{array}{l}\text { Equal variances } \\
\text { assumed }\end{array}$ & -4.4442 & 371 & 0.0000 & -4.1 & 0.92255 & -5.914083 & -2.285917 \\
\hline $\begin{array}{l}\text { Equal variances not } \\
\text { assumed }\end{array}$ & -3.8995 & 147.773 & 0.0001 & -4.1 & 1.051425 & -6.177771 & -2.022229 \\
\hline
\end{tabular}

Note: Cohen's $d=-0.451,1-\beta=0.972$

Table 5

Extraversion t-test between pilot students and non-pilot students

\begin{tabular}{|c|c|c|c|c|c|c|c|}
\hline \multirow[t]{3}{*}{ (E) Extraversion } & \multicolumn{7}{|c|}{ T-test for Equality of Means } \\
\hline & \multirow[b]{2}{*}{$\mathrm{t}$} & \multirow[b]{2}{*}{ df } & \multirow[b]{2}{*}{ Sig. (2-talied) } & \multirow{2}{*}{$\begin{array}{c}\text { Mean } \\
\text { Difference }\end{array}$} & \multirow{2}{*}{$\begin{array}{l}\text { Std. Error } \\
\text { Difference }\end{array}$} & \multicolumn{2}{|c|}{$\begin{array}{l}95 \% \text { Confidence } \\
\text { Interval of the } \\
\text { Difference }\end{array}$} \\
\hline & & & & & & Lower & Upper \\
\hline $\begin{array}{l}\text { Equal variances } \\
\text { assumed }\end{array}$ & 0.1201 & 371 & 0.9044 & 0.1 & 0.8323217 & -1.53666 & 1.73666 \\
\hline $\begin{array}{l}\text { Equal variances not } \\
\text { assumed }\end{array}$ & 0.1009 & 138.703 & 0.9189 & 0.1 & 0.990999 & -1.859418 & 2.059418 \\
\hline
\end{tabular}

Note: Cohen's $d=0.012,1-\beta=0.050$

Table 6

Openness to Experience t-test between pilot students and non-pilot students

\begin{tabular}{|c|c|c|c|c|c|c|c|}
\hline \multirow[t]{3}{*}{ (0) Openness to experience } & \multicolumn{7}{|c|}{ T-test for Equality of Means } \\
\hline & \multirow[b]{2}{*}{$\mathrm{t}$} & \multirow[b]{2}{*}{$\mathrm{df}$} & \multirow[b]{2}{*}{ Sig. (2-talied) } & \multirow{2}{*}{$\begin{array}{c}\text { Mean } \\
\text { Difference }\end{array}$} & \multirow{2}{*}{$\begin{array}{l}\text { Std. Error } \\
\text { Difference }\end{array}$} & \multicolumn{2}{|c|}{$\begin{array}{l}95 \% \text { Confidence } \\
\text { Interval of the } \\
\text { Difference }\end{array}$} \\
\hline & & & & & & Lower & Upper \\
\hline $\begin{array}{l}\text { Equal variances } \\
\text { assumed }\end{array}$ & -0.4857 & 371 & 0.6275 & -0.4 & 0.8236299 & -2.019568 & 1.219568 \\
\hline $\begin{array}{l}\text { Equal variances not } \\
\text { assumed }\end{array}$ & -0.3953 & 133.054 & 0.6932 & -0.4 & 1.011772 & -2.401239 & 1.601239 \\
\hline
\end{tabular}

Note: Cohen's $d=0.046,1-\beta=0.068$ 
Table 7

Agreeableness $t$-test between pilot students and non-pilot students

\begin{tabular}{|c|c|c|c|c|c|c|c|}
\hline \multirow[t]{3}{*}{ (A) Agreeableness } & \multicolumn{7}{|c|}{ T-test for Equality of Means } \\
\hline & \multirow[b]{2}{*}{$\mathrm{t}$} & \multirow[b]{2}{*}{ df } & \multirow[b]{2}{*}{ Sig. (2-talied) } & \multirow{2}{*}{$\begin{array}{c}\text { Mean } \\
\text { Difference }\end{array}$} & \multirow{2}{*}{$\begin{array}{l}\text { Std. Error } \\
\text { Difference }\end{array}$} & \multicolumn{2}{|c|}{$\begin{array}{l}95 \% \text { Confidence } \\
\text { Interval of the } \\
\text { Difference }\end{array}$} \\
\hline & & & & & & Lower & Upper \\
\hline $\begin{array}{l}\text { Equal variances } \\
\text { assumed }\end{array}$ & 1.7134 & 371 & 0.0875 & 1.3 & 0.7587273 & -0.1919452 & 2.791945 \\
\hline $\begin{array}{l}\text { Equal variances not } \\
\text { assumed }\end{array}$ & 1.3881 & 132.246 & 0.1674 & 1.3 & 0.9364983 & -0.5524544 & 3.152454 \\
\hline
\end{tabular}

Note: Cohen's $d=0.161,1-\beta=0.283$

Table 8

Conscientiousness t-test between Student Pilots and Non-Pilot Sample

\begin{tabular}{|c|c|c|c|c|c|c|c|}
\hline \multirow[t]{3}{*}{ (C) Conscientiousness } & \multicolumn{7}{|c|}{ T-test for Equality of Means } \\
\hline & \multirow[b]{2}{*}{$\mathrm{t}$} & \multirow[b]{2}{*}{ df } & \multirow[b]{2}{*}{ Sig. (2-talied) } & \multirow{2}{*}{$\begin{array}{l}\text { Mean } \\
\text { Difference }\end{array}$} & \multirow{2}{*}{$\begin{array}{l}\text { Std. Error } \\
\text { Difference }\end{array}$} & \multicolumn{2}{|c|}{$\begin{array}{l}95 \% \text { Confidence } \\
\text { Interval of the } \\
\text { Difference }\end{array}$} \\
\hline & & & & & & \begin{tabular}{|l|} 
Lower \\
\end{tabular} & Upper \\
\hline $\begin{array}{l}\text { Equal variances } \\
\text { assumed }\end{array}$ & 0.9454 & 371 & 0.3451 & 0.8 & 0.8461759 & -0.8639023 & 2.463902 \\
\hline $\begin{array}{l}\text { Equal variances not } \\
\text { assumed }\end{array}$ & 0.7733 & 133.876 & 0.4407 & 0.8 & 1.034525 & -1.246128 & 2.846128 \\
\hline
\end{tabular}

Note: Cohen's $d=0.09,1-\beta=0.121$

\section{Discussion}

Using API, this study found that Agreeableness (A) and Conscientiousness (C) are the two most dominant personality scales for pilot students, accounting for over $60 \%$ of the pilot student sample. Strong Agreeableness indicates that pilot students have greater tendencies towards cooperative behavioural traits. They generally have a more optimistic view about human nature, get along well with others, and are friendly, warm and tactful. Meanwhile, Conscientiousness means that pilot students have a strong desire to do well and are highly efficient and organised. Interestingly, Callister (1999) studied personality characteristics of 1,301 U.S. Air Force student pilots and found lower levels of agreeableness, compared with adult norms of both genders. The difference in the Agreeableness scale between the current study and Callister (1999) suggests that the training environment (civil or military) or the different selection criteria could be contributing factors, which calls for further studies. 
In terms of strong Conscientiousness, this study conforms to some previous studies which suggested higher levels of Conscientiousness (Fitzgibbons et al., 2004; Carretta et al., 2014), highly competitive (Picano, 1991; Callister, 1999) achievement striving (Hormann \& Maschke, 1996; Callister, 1999; Lambirth et al., 2009) and highly motivated (Chidester et al., 1991) among the pilot population. Such finding supports the notion that pilot students are aware of the challenges to achieve success in aviation.

In terms of the least dominate personality scale, Neuroticism (N) stands out of all five scales with an overwhelming percentage of $83.65 \%$. The extremely low representation of Neuroticism indicates that pilot students are less anxious, less moody, less envious, less frustrated, less jealous, less lonely, less worried and usually have low levels of fear. These findings are consistent with Callister's (1999) study in which pilots were found to be highly competent, responsible and were observed as being able to cope with high levels of stress.

When comparing pilot students with non-pilot students represented by the psychology student sample of Murray et al. (2009), it was found that the Neuroticism (N) scale of the pilot student sample is significantly lower than nonpilot students, but no significance could be found on the other four scales. The low level of Neuroticism supports the occupation role of a pilot, particularly in being less anxious, displaying low levels of fear and less stressed in times of emergencies. Failure to detect significance on four out of five personality scales between pilot students and non-pilot students could be attributed by the fact that students' overall exposure to their respective professional environment is rather limited, considering they are still in the early stages of training. Therefore, the impact of the aviation profession on personality scales, if there is any, is negligible.

Understanding personality types of pilot students and the difference to non-pilot students provides useful information to the body of literature surrounding pilot training and personalities. Such results, coupled with learning style studies (Kanske \& Brewster, 2001; Fanjoy \& Gao, 2011; Harriman, 2011; Gao, Au, Kwon \& Leong, 2013), have the potential of being used by flight training providers to customise the training syllabus and instructing styles in order to better cater for the students' need and to improve their training performance.

The current study has its limitations. Findings of this study are based on pilot students sample recruited from the aviation program with which researchers are affiliated, therefore, they should not be generalised to represent the entire pilot student population of Australia without further study. The non-pilot student sample is also limited only to psychology students recruited by Murray et al. (2009). To date, there are only a limited number of studies using API as their choice of instrument, making it challenging to compare the results of this study to others. Convenience sampling, which is not random sampling by nature, used by this study, 
may bring in bias as it is quite likely that students of certain personality types are more willing to participate in the survey, hence affecting the sample from being a fair representative of the student pilot population.

\section{Conclusion}

This study serves to shed some light on the issue of personality types in pilot training through identifying the most and least dominant personality scales among the pilot students and through comparing pilot students with non-pilot students. It is beyond the scope of this study to analyse if students' personalities are shaped by the training environment they are in or students of certain personality types are more likely to select piloting as their career. However, this can be a worthwhile direction for future studies to explore. 


\section{References}

Bartram, D. (1995). The predictive validity of the EPI and 16PF for military flying training. Journal of Occupational and Organizational Psychology, 68(3), 219-236.

Callister, J. (1999). Revised NEO personality inventory profiles of male and female U.S. Air Force Pilots. Military Medicine, 164(12), 885-890.

Carretta, T., Teachout, M., Ree, M., Barto, E., King, R., \& Michaels, C. (2014). Consistency of the relations of cognitive ability and personality traits to pilot training performance. The International Journal of Aviation Psychology, 24(4), 247-264.

Chidester, T., Helmreich, R., Gregorich, S., Geis, C. (1991). Pilot personality and coordination: Implications for training and selection. The International Journal of Aviation Psychology, 1(1), 25-44.

Dillinger, T., Wiegmann, D., \& Taneja, N. (2003). Relating personality with stress coping strategies among student pilots in a collegiate flight training program, 12th International Symposium on Aviation Psychology. Illinois: University of Illinois.

Fanjoy, R. O., \& Gao, Y. (2011). Learning styles of Chinese aviation students. International Journal of Applied Aviation Studies. 11(1), 57-65.

Fitzgibbons, A., Schutte, P., \& Davis, D. (2004). Pilot personality profile using NEO-PI-R. National Aeronautics and Space Administration. Retrieved from http://ntrs.nasa.gov/archive/nasa/casi.ntrs.nasa.gov/20040191539.pdf.

Flin, R., \& Slaven, G. (1996). Personality and emergency command ability. Disaster Prevention and Management: An International Journal, 5(1), 40 46.

Friedman, H., \& Schustack, M. (2012). Personality: classic theories and modern research (5th ed.). Boston: Pearson Allyn \& Bacon.

Ganesh, A., \& Joseph, C. (2005). Personality studies in aircrew: An overview. Indian Journal of Aerospace Medicine, 49(1), 54-62.

Gao, Y., Au, K. T. S., Kwon, H. J., \& Leong, E. W. (2013). Learning styles of Australian aviation students: An assessment of the impact of culture. Collegiate Aviation Review, 31(1), 17-26. 
Hamilton, R. (2007). Machiavellianism and Personality Typing as Determinants for Screening Commercial Pilot Candidates. Collegiate Aviation Review, 12(1), 28-35.

Harriman, S. L. (2011). The impact of collegiate aviation student learning styles on flight performance: A scenario-based training approach (Doctoral dissertation). Retrieved from ProQuest Dissertations and Theses - West Lafayette, Indiana. (UMI 347949)

Hormann, H., \& Maschke, P. (1996). On the relation between personality and job performance of airline pilots. The International Journal of Aviation Psychology, 6(2), 171-178.

Kanske, C. A., \& Brewster, L. T. (2001). The learning styles of college aviation students. Collegiate Aviation Review, 19(1), 62-70.

Lambirth, T., Doglin, D., Rentmeister-Bryant, H., \& Moore, J. (2003). Selected personality characteristics of student naval aviators and student flight officers. The International Journal of Aviation Psychology, 13(4), 415427.

Murray, G., Judd, F., Jackson, H., Fraser, C., Komiti, A., Pattison, P., \& Robins, G. (2009). Personality for free: Psychometric properties of a public domain Australian measure of the five-factor model. Australian Journal of Psychology, 61(3), 167-174.

Picano, J. J. (1991). Personality types among experienced military pilots. Aviation, Space, and Environmental Medicine, 62(6), 517-520.

Roen, G. D. (1991). Is peter pan flying your plane? In Deitz, S. R., \& Thoms, W. E. (1991). Pilots, personality, and performance (pp. 71-84). New York: Quorum Books.

Ryckman, R. (2013). Theories of Personality (10th ed.). San Francisco: Cengage Advantage Books.

Ramachandran, N., Wadhawan, J., Chandramohan, V., \& Rao, P. (1983). Personality profile of an IAF Pilot: Its usefulness in pilot selection. Aviation Medicine, 21(1), 131-139.

Robertson, M., \& Putnam, A. (2008). Personality types of student pilots admitted to the aviation flight program at Southern Illinois University Carbondale. Collegiate Aviation Review, 26(1), 111-124. 


\section{Appendix}

Australian Personality Inventory (API)

Questionnaire Identification Number

The following items contain phrases describing people's typical behaviours. Please use the rating scale below to describe how accurately each statement describes you generally. Describe yourself as you honestly see yourself, in relation to other people you know of the same sex as you are, and roughly your same age.

\begin{tabular}{|c|c|c|c|c|c|c|}
\hline \multirow[t]{2}{*}{ \# } & \multirow{2}{*}{ 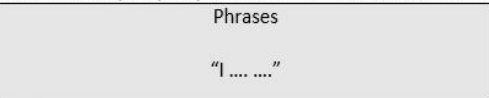 } & \multicolumn{5}{|c|}{ Your Response (Please only tick one response for each phrase: V) } \\
\hline & & $\begin{array}{c}\text { Very } \\
\text { inaccurate }\end{array}$ & $\begin{array}{l}\text { Moderately } \\
\text { inaccurate }\end{array}$ & $\begin{array}{c}\text { Neither } \\
\text { inaccurate } \\
\text { nor accurate }\end{array}$ & $\begin{array}{c}\text { Moderately } \\
\text { accurate }\end{array}$ & $\begin{array}{l}\text { Very } \\
\text { accurate }\end{array}$ \\
\hline 1 & Often feel blue. & & & & & \\
\hline 2 & Feel comfortable around people. & & & & & \\
\hline 3 & Do not like art. & & & & & \\
\hline 4 & Have a good word for everyone. & & & & & \\
\hline 5 & Am always prepared. & & & & & \\
\hline 6 & Dislike myself. & & & & & \\
\hline 7 & Make friends easily. & & & & & \\
\hline 8 & Have a vivid imagination. & & & & & \\
\hline 9 & Believe that others have good intentions. & & & & & \\
\hline 10 & Pay attention to details. & & & & & \\
\hline 11 & Am often down in the dumps. & & & & & \\
\hline 12 & Am skilled in handling social situations. & & & & & \\
\hline 13 & Have a rich vocabulary. & & & & & \\
\hline 14 & Respect others. & & & & & \\
\hline 15 & Get chores done right away. & & & & & \\
\hline 16 & Have frequent mood swings. & & & & & \\
\hline 17 & Am the life of the party. & & & & & \\
\hline 18 & Carry the conversation to a higher level. & & & & & \\
\hline 19 & Accept people as they are. & & & & & \\
\hline 20 & Carry out my plans. & & & & & \\
\hline 21 & Panic easily. & & & & & \\
\hline 22 & Know how to captivate people. & & & & & \\
\hline 23 & Enjoy hearing new ideas. & & & & & \\
\hline 24 & Make people feel at ease. & & & & & \\
\hline \multirow[t]{2}{*}{25} & Make plans and stick to them. & & & & & \\
\hline & & $\begin{array}{c}\text { Very } \\
\text { inaccurate }\end{array}$ & $\begin{array}{c}\text { Moderately } \\
\text { inaccurate }\end{array}$ & $\begin{array}{c}\text { Neither } \\
\text { inaccurate } \\
\text { nor accurate }\end{array}$ & $\begin{array}{c}\text { Moderately } \\
\text { accurate }\end{array}$ & $\begin{array}{c}\text { Very } \\
\text { accurate }\end{array}$ \\
\hline 26 & Seldom feel blue. & & & & & \\
\hline 27 & Have little to say. & & & & & \\
\hline 28 & Am not interested in abstract ideas. & & & & & \\
\hline 29 & Have a sharp tongue. & & & & & \\
\hline 30 & Waste my time. & & & & & \\
\hline 31 & Feel comfortable with myself. & & & & & \\
\hline 32 & Keep in the background. & & & & & \\
\hline 33 & Enjoy wild flights of fantasy. & & & & & \\
\hline 34 & Cut others to pieces. & & & & & \\
\hline 35 & Find it difficult to get down to work. & & & & & \\
\hline 36 & Rarely get irritated. & & & & & \\
\hline 37 & Would describe my experiences as somewhat dull. & & & & & \\
\hline 38 & Avoid philosophical discussions. & & & & & \\
\hline 39 & Suspect hidden motives in others. & & & & & \\
\hline 40 & Do just enough work to get by. & & & & & \\
\hline 41 & Am not easily bothered by things. & & & & & \\
\hline 42 & Don't like to draw attention to myself. & & & & & \\
\hline 43 & Do not enjoy going to art museums. & & & & & \\
\hline 44 & Get back at others. & & & & & \\
\hline 45 & Don't see things through. & & & & & \\
\hline 46 & Am very pleased with myself. & & & & & \\
\hline 47 & Don't talk a lot. & & & & & \\
\hline 48 & Rarely look for a deeper meaning in things. & & & & & \\
\hline 49 & Insult people. & & & & & \\
\hline 50 & Shirk my duties. & & & & & \\
\hline
\end{tabular}

